HEALTH AND SAFETY' RESEARCH DIVISION

Environmental Restoration and Waste Management Non-Defense Programs

(Activity No. EX $2020010 ;$ ADS $317(\times(\times)$ ))

\title{
Radiological Survey Results at 19 Wellman Street, Beverly, Massachusetts (VB024)
}

R. D. Foley and C. A. Johnson

Date published -..July 1992

Investigation Team

R. E Swaja - Measurement Applications and Development Manager

W. D. Cottrell --.. FUSR.AP Projed Director

R. D. Foley - Survey 'Team Leader

Survey Team Members
J. F. Allred
M. E. Murray
A. C. Butler*
V. P. Patania
R. D. Foley
D. E. Rice
D. Mackenzict
D. A. Rose

W. H. Shinpaugh*

*D. R. Stone and Associates, Inc.

tH\&R Technical Associates

Work performed by the

MEASUREMENT APPLICATIONS AND DEVELOPMENT GROUP

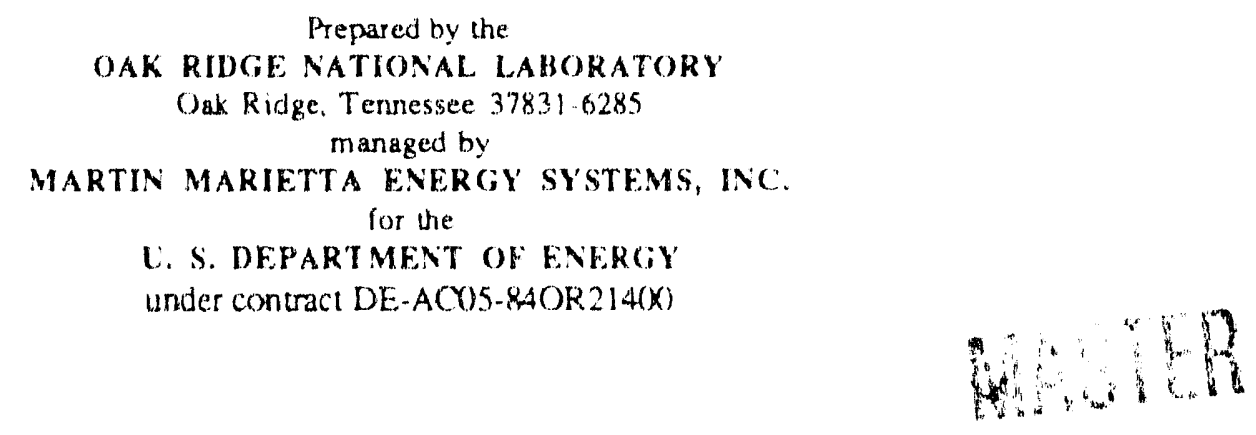




\section{CONTENTS}

LIST OF FIGURES ..........................................

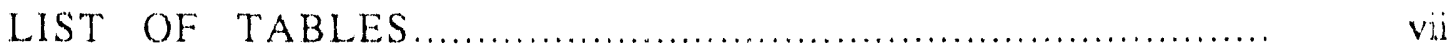

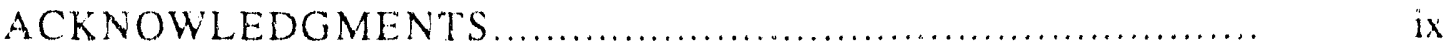

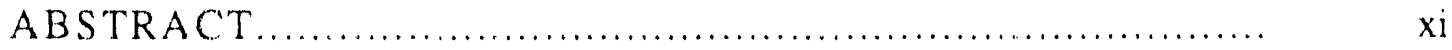

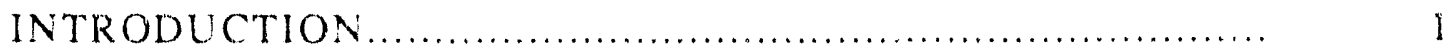

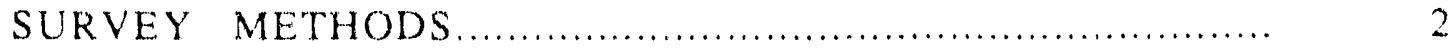

SURFACE RADIATION MEASUREMENTS ........................ 2

SOIL SAMPLING AND ANAL YSES ............................. 2

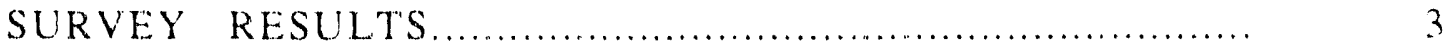

SURFACE RADIATION MEASUREMENTS ......................

SOIL SAMPLES ...............................................

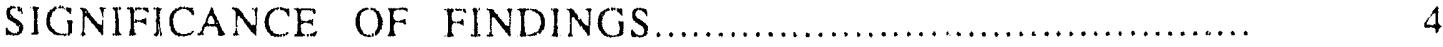

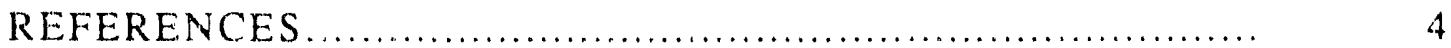




\section{LIST OF FIGURES}

1 Diagram showing gencral lociation of the former Ventron site................. 5

2 Diagram showing relative location of 19 Wellman Strel, Beverly, Massachusetts, to the former Ventron sile ............................................... o

3 Surface gamma exposure rates and soil sampling locations at 19 Wellman Streei, Beverly, Massachusetts.............................................. 


\section{LIST OF TABLES}

1 Applicable guidelines for protection against radiation............................. 8

2 Background radiation levels and concentrations of sclected

radionuclides in soil in the Beverly, Massachusetts, are a.......................... 9

3 Concentrati ns of radionuclides in soil samples from 19 Wellman Streat,

Beverly, Massachusetts....................................................... 10 


\section{ACKNOWLEDGMENTS}

Research for this project was sponsored by the Office of Environmenti I Restoration, U.S. Department of Energy, under contract DE-ACO5-840R21400 with …untin Maricta Energy Systems, Inc. The authors $w$ ish to acknowledge the contributions of $k$. F. Carrier, W. D. Cottrell, M. S. Uziel, D. A. Roberts, D. A. Rose, V. P. Patania, J. F. Allred, and T. R. Stewan of the Measurement Applicitions and Development Group who participated in the sample preparation and analyses, ediing, graphics, and reporting of data for this survey. 


\begin{abstract}
At the request of the U.S. Department of Energy (DOE), a team from Oak Ridge National Laboratory conducted a radiological survey at 19 Wellman Street. Beverly, Massachusetts. The survey was performed in May 1991. The purpose of the survey was to determine if uranium from work perfomed under government contract at the former Ventron facility had migrated off-site to neighboring areas. The survey included a surface gamma scan, a beta-gamma scan of paved areas, and the collection of soil samples for radionuclide analyses.
\end{abstract}

Results of the survey demonstrated no radionuclide concentrations or radiation measurements in excess of the DOE Formerly Utilized Sites Remedial Action Program guidelines. 


\section{RADIOLOGICAL SURVEY RESULTS AT 19 WELLMAN STREET, BEVERLY, MASSACHUSETTS $(\mathrm{VBO24})^{*}$}

\section{INTRODUCTION}

The Metal Hydrides Corporation facility in Beverly, Massachusetts (which became the Ventron Corporation in 1965), was one of many companies performing work during the 1940 s associated with the development of nuclear energy for defense-related projects under contract to the Manhattan Engineer District (MED) and the Atomic Energy Commission (AEC). Operations conducted under government contract at such sites included the procurement, storage, and processing of uranium oxides, salts, and metals, and the subsequent machining of these products. As a result of activities involving these materials, equipment, buildings, and land at some of the sites became radiologically contaminated with small amounts of the material resulting in low levels of contamination on the properties. At contract termination, release lirnits and decontamination operations were typically applied in conformance with standards currently deemed adequate for purposes of health and environmental protection. Subsequent to original assessments and the release of these facilities, new research and information have resulted in the development of more stringent guidelines for release of such facilities for unrestricted use. Furthermore, in some instances, documentation is limited or nonexistent, and conditions at a specific site may be unknown. It is the policy of the Department of Energy (DOE) to verify that radiological conditions at such facilities comply with existing guidelines. 1 The Formerly Utilized Sites Remedial Action Program (FUSR.AP) was established by DOE to assist in assessment and cleanup activities at these sites.

The radiological survey detailed in this report was performed under the FUSRAP program and is one of several conducted in May, 1991, on properties in the vicinity of the former Ventron facility by members of the Oak Ridge National Laboratory (ORNL) at the request of DOE. The city of Beverly lies on Beverly Harbor approximately 15 miles northeast of the central Boston area. The former Ventron facility, now owned by Morton International, Inc., is located at the confluence of the Bass and Danvers rivers on Congress Street near the Beverly-Salem bridge (Fig.1, p. 5).

From 1942 through 1948 the Metal Hydrides Corporation (later to become the Ventron facility) converted uranium oxide to uranium metal powder at the facility under contract to the MED in suppon of the war effort. Other operations conducted at the facility included the recovery of uranium from scrap uranium and turnings from the slug fabrication plant at Hanford, Washington. Contracts between Metal Hydrides and the govemment were completed in 1954.

"The survey was performed by members of the Measurement Applications and Development Group of the Health and Safety Research Division of Oak Ridge National Laboratory under DOE contract DE-AC05. $840 R 21400$. 
Following a radiological screening survey at the site in 1977, a comprehensive survey was performed in 1982.2 In 1987, DOE contractors removed the uranium-contaminated roof from a Ventron building, which had begun to leak. Radioactive materials remaining on the site do not pose a health hazard under present use conditions, but could cause radiation exposure to workers if excavation or major renovation took place on the prorsrty. DOE plans a complete characterization study of the site in 1992 and the initiation of remedial action soon thereafter.

The surveys of the property reported in this document and of other surrounding properties are part of DOE's continuing program to assess the former Ventron site and plan for remedial action. The objective of the surveys was to determine if uranium from plant operations had migrated of fsite to neighboring areas including Beverly Harbor and, if so, to what degree. The relative location of this vicinity property to the former Ventron site is shown in Fig. 2 (p. 6). The radiological surveys consisted of measurements of radiation levels over the ground surface of the properties and analysis of soil, sediment, and other material samples for the presence of radionuclides in concentrations exceeding guidelines.

\section{SUR VEY METHODS}

A comprehensive description of the survey methods and instrumentation is presented in Procedures Manual for the ORNL Radiological Survey Activities (RASA) Program, ORNL/TM-8600 (April 1987). ${ }^{3}$

\section{SURFACE RADIATION MEASUREMENTS}

Gamma radiation levels were determined using a portable Nal gamma scintillation meter. Because Nal gamma scintillators are energy dependent, measurements of gamma radiation levels in counts per minute $(\mathrm{cpm})$ are normalized to pressurized ionization chamber (PIC) measurements to estimate gamma exposure rates in $\mu \mathrm{R} / \mathrm{h}$. Using a Geiger-Mueller pancake detector, beta-gamma radiation levels in $\mathrm{cpm}$ were measured over paved surfaces and then converted to $\mathrm{mrad} / \mathrm{h}$.

\section{SOIL SAMPLING AND ANALYSES}

Surface and subsurface soil samples were systematically collected over the propery in a pattem sufficient to obtain a characterization of the radionuclide content of the soil. Surface and subsurface soil samples were also collected in any areas of elevated gamma exposure rates. All soil samples were analyzed to determine $238 \mathrm{U}, 232 \mathrm{Th}$, and $226 \mathrm{Ra}$ concentrations. 


\section{SURVEY RESULTS}

Current guidelines for sites included within the FUSRAP are summarized in Table 1 (p. 8). Typical background radiation levels for the Beverly. Massachusetts area are presented in Table 2 (p. 9). These data are provided for comparison with the survey results presented in this section. All direct measurements presented in this report are gross readings; background radiation levels have not been subtracted. Similarly, background concentrations have not been subtracted from radionuclide concentrations in soil, debris, and oiher samples.

\section{SURFACE RADIATION MFASUREMENTS}

Results of gamma scanning at the ground surface of the property are shown on Fig. 3 (1. 7). Exposure rates at the ground surface of the property ranged from $71010 \mu \mathrm{R} / \mathrm{h}$, with a maximum of $13 \mu \mathrm{R} / \mathrm{h}$ measured on contact with the granite foundation of the house (see Fig. 3). (Granite usually contains slightly greater concentrations of naturally occurring radionuclides than soil). These values are comparable to the typical background measurements in the Beverly, Massachusetts, arca (6 to $9 \mu \mathrm{R} / \mathrm{h}$, Table 2).

Beta-garnma dose rates ranging from $.03 \mathrm{mrad} / \mathrm{h}$ over paved surfaces 10 a maximum of .06 $\mathrm{mrad} / \mathrm{h}$ on granite were measured on the property. All measurements are comparable to background levels in the area.

\section{SOIL SAMPLES}

Although ${ }^{137} \mathrm{Cs}$ was not associated with any MED operations or processing activities at the Ventron site, samples are routinely analyzed for its presence. These analyses showed that samples S1A, S1B, and S1C, lineasured on the nonth side of the deck where a drainpipe from the roof emptied onto the soil, contained $6.7,4.4$ and $3.4 \mathrm{pCi} / \mathrm{g}$ of $137 \mathrm{Cs}$ respectively (decreasing with soil depth). Although these concentrations are slightly higher than those typically found in background areas, they are well below the guideline for ${ }^{137} \mathrm{Cs}$ (Table 1 ). Cesium-137 is a man-made radionuclide present worldwide in atmospheric fallout from nuclear weapons testing. It is frequently found in soil taken from areas where rainwater collects, such as the driplines of roofs and low-lying areas in and around parking lots or thoroughfares.

Maximum concentrations of $238 \mathrm{U},{ }^{232} \mathrm{Th}$, and $226 \mathrm{Ra}$ in surface soil $(0-15 \mathrm{~cm})$ were 3.3 , and $3.1 \mathrm{pCi} / \mathrm{g}$, respectively. In subsurface soil $(15-60 \mathrm{~cm})$, where coal ash was prevalent, maximum values were $5.4 \mathrm{pCi} / \mathrm{g}$ for $238 \mathrm{U}, 4.5 \mathrm{pCi} / \mathrm{g}$ for $232 \mathrm{Th}$, and $4.3 \mathrm{pCi} / \mathrm{g}$ for $226 \mathrm{Ra}$. Coal ash contains naturally occurring radioactive substances which become concentrated in the ash that results from combustion. Therefore, these values are slightly higher than the typical Beverly area background concentrations for $238 \mathrm{U}, 232 \mathrm{Th}$, and $226 \mathrm{Ra}$ (Table 2), but are well below the guidelines (Table 1). Although no specific guideline for uranium concentrations 
has been derived for this site, concentrations of 35 to $40 \mathrm{pCi} / \mathrm{g}$ have been applied at FUSRAP sites elsewhere (Table 1), and the analyses demonstrate that concentrations of $238 \mathrm{U}$ are well below these values. Locations of systematic soil samples are diagrammed in Fig. 3 and results of analyses are listed in Table 3 (p. 10).

\section{SIGNIFICANCE OF FINDINGS}

The results of the radiological survey at 19 Wellman Street, Beverly, Massachusctts, demonstrated no radionuclide concentrations or radiation measurements above established DOE guidelines.

\section{REFERENCES}

1. U.S. Department of Energy, A Background Report for the Formerly Utilized Manhattan Engineer District/Atomic Energy Commission Sites Program, DOE/EV-0097, September 1980.

2. W. D. Cottrell and R. F. Carrier, Results of the Radiological Survey at the Ventron Site, Beverly, Massachusetts, ORNL/TM-10053, Martin Marietta Energy Systems, Inc., Oak Ridge Natl. Lab., May 1988.

3. T. E. Myrick, B. A. Berven, W. D. Cottrell, W. A. Goldsmith, and F. F. Haywood, Procedures Manual for the ORNL Radiological Survey Activities (RASA) Program, ORNL/TM-8600, Martin Marietta Energy Systems, Inc., Oak Ridge Natl. Lab., April 1987. 


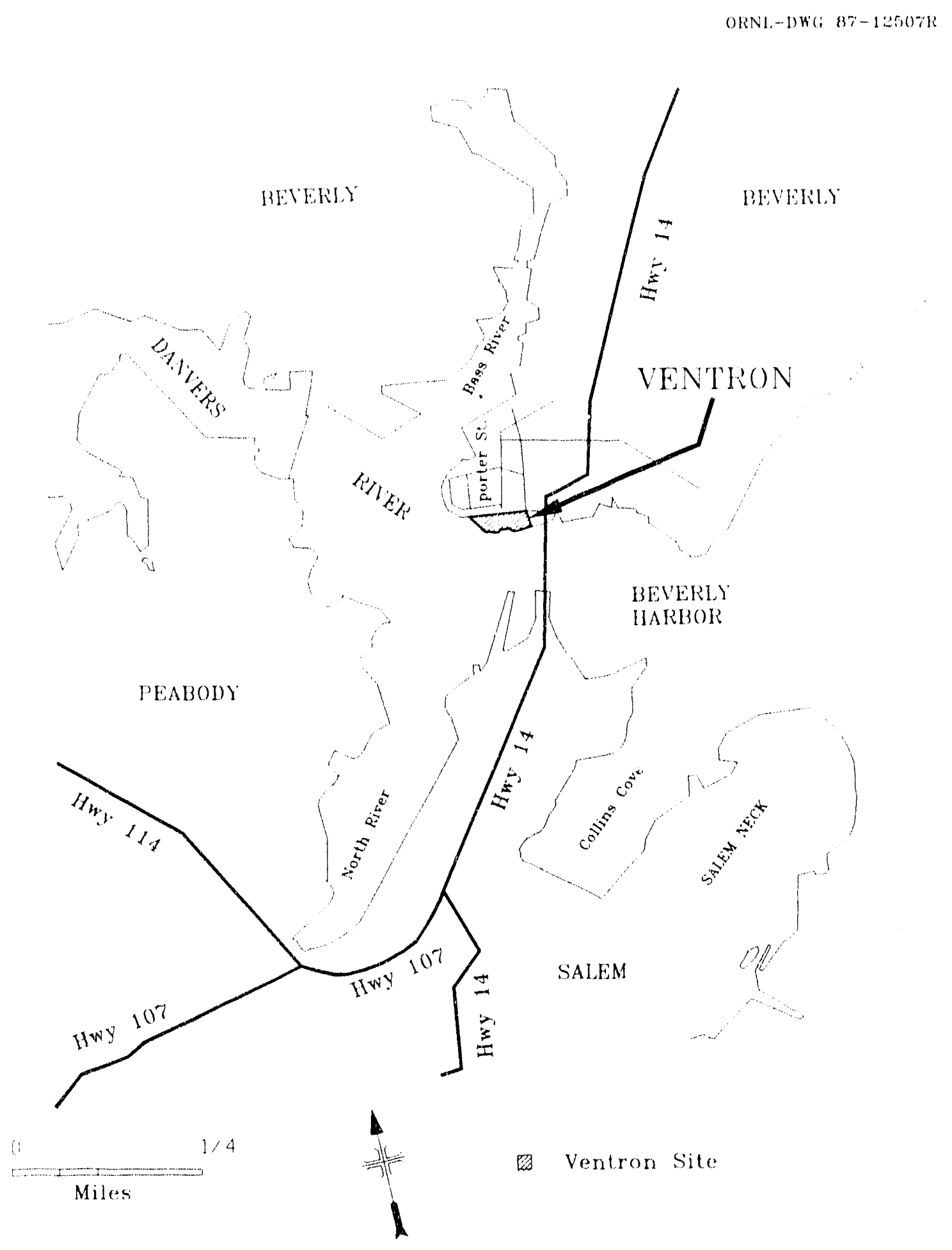

Fig. 1. Diagram showing general location of the former Ventron site. 


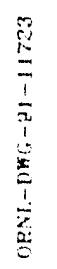

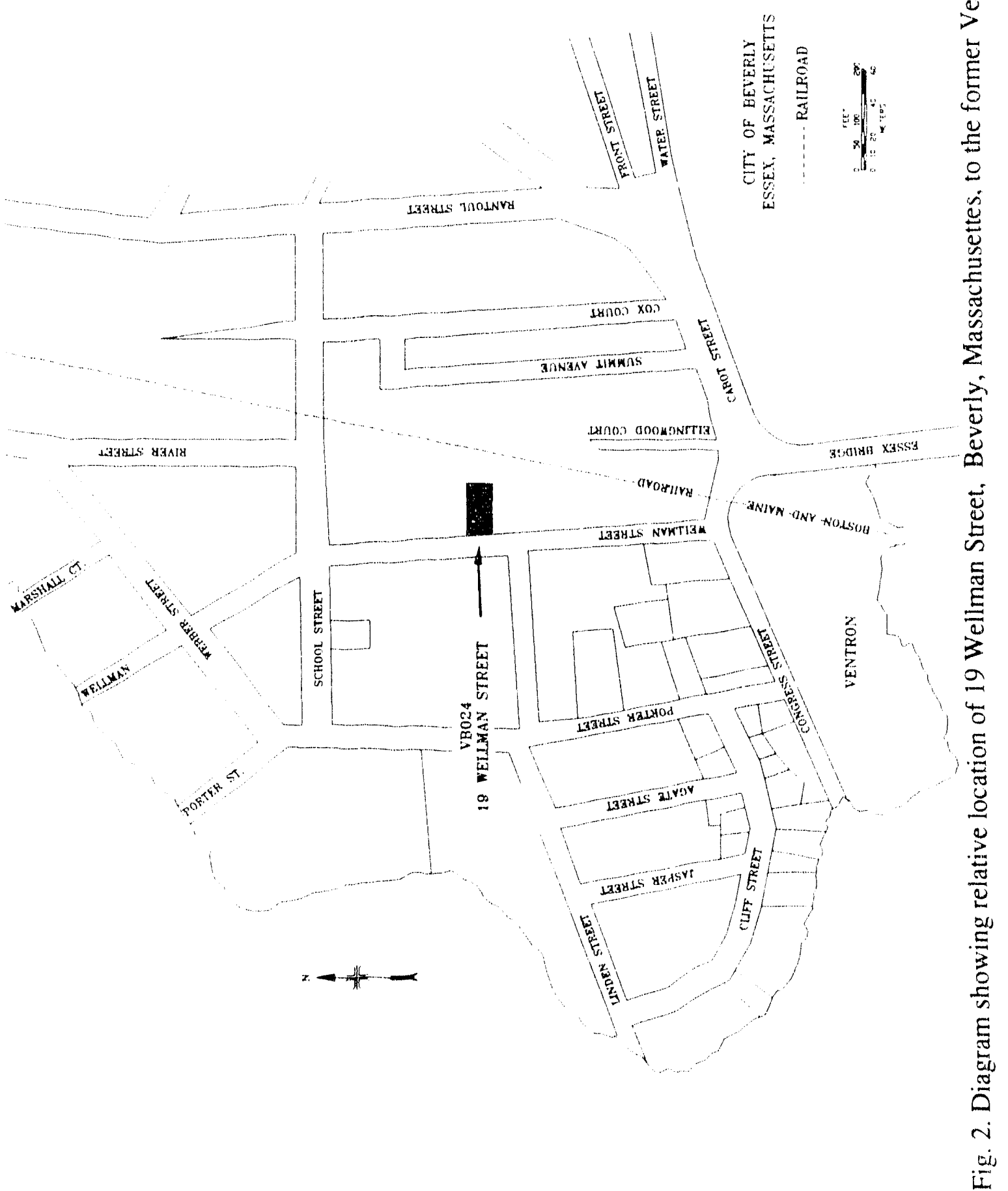




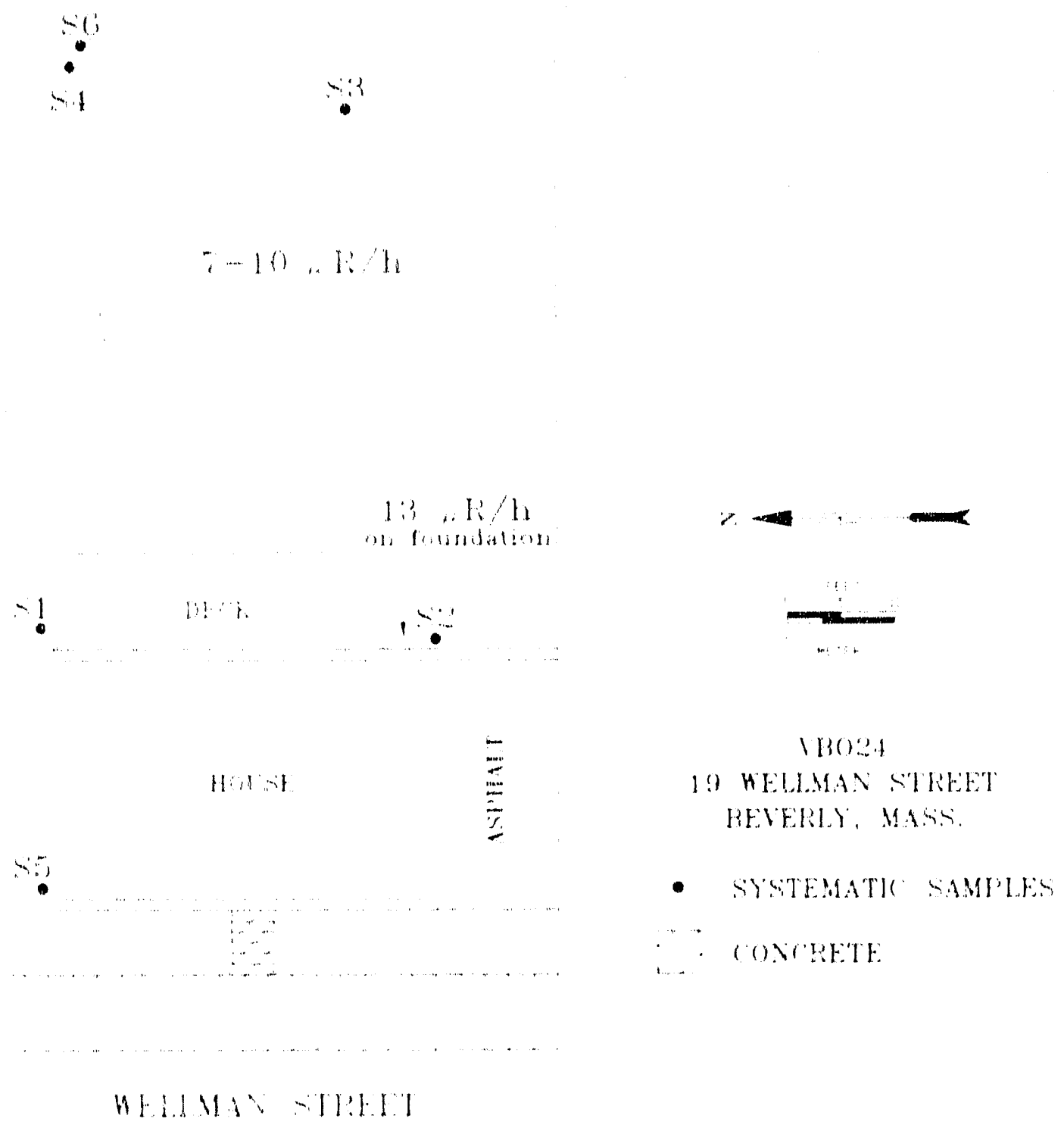

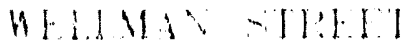

Fig. 3. Surface fiamma exposure rates and son sampling locations at 19 Wellman Street. Beverly. Masuahthuen, 
Table 1. Applicable guidelines for protection against radiation (Limits for $u$-untrolled arcas)

Mode of exposure

Exposure conditions

Guideline value

Gamma radiation

Indoor gamma radiation level (above background)

Radionuclide concentrations in soil (generic)

Maximum permissible concentration of the following radionuclides in soil above background levels, averaged over a $100-\mathrm{m}^{2}$ area

$$
\begin{aligned}
& 226 \mathrm{Ra} \\
& 232 \mathrm{Th} \\
& 230 \mathrm{Th}
\end{aligned}
$$

Derived concentrations

$$
238 \mathrm{U}
$$

$$
20 \mu R / h^{3}
$$

$5 \mathrm{pCi} / \mathrm{g}$ averaged over the first $15 \mathrm{~cm}$ of soil below the surface; 15 $\mathrm{pCi} / \mathrm{g}$ when averaged over $15 \mathrm{~cm}$-thick soil layers $>15 \mathrm{~cm}$

below the surface

Concentration limit in surface soil above background levels based on dose estimates from major exposure pathways ${ }^{137} \mathrm{Cs}$

$80 \mathrm{pCi} / \mathrm{g}$ over a $100-\mathrm{m}^{2}$ area of contamination

Guideline for non-

Applicable to locations with homogeneous contamination (used in an area $\leq 25 \mathrm{~m}^{2}$. with signifi. cantly elevated concentrations addition to the $100-\mathrm{m}^{2}$ guideline $)^{d}$

$G_{A}=G_{i}(1(0) / A)^{1 / 2}$

where

$G_{A}=$ guideline for "hot

spot" of area $(A)$

$G_{1}=$ guideline averaged

over a $100-\mathrm{m}^{2}$ area

\footnotetext{
$a^{\prime}$ The $20 \mu R / \mathrm{h}$ shall comply with the basic dose limit $\left.(100) \mathrm{mrem} / \mathrm{yr}\right)$ when an appropriate-use scenario is considered.

bDOE guidelines for uranium are derived on a sile-specific basis. Guidelines of 35-40 pCi/g have been applicd at other FUSRAP sites. Sources: J. L. Marley and R. F. Carrier, Results of the Radiological Survey at 4 Eimhursi Avenue. Colonie, New York (AL.219), ORNL/RASA-87/117, Martin Marietta Energy Systems, Inc., Oak Ridge Nat]. Lab., February 1988; B. A. Berven el. al., Radiological Survey of the Former Kellex Research Facility, Jersey City. New Jersey, DOE/E V-OC05/29, ORNL-5734, Martin Marietti Energy Systems, Inc., Cak Ridge Nat. Lab., February 1982.

cJ. W. Healy, J. C. Rodgers, and C. L. Wienke, Interim Soil Limits for D\&D Projects, LA-UR-79-1865Rev., Los Alamos Scientific Laboratory, Los Alamos, NM, 1979. Cited in U. S. Department of Energy, Radiologicai Guidelines for Applicalion to DOE's Formerly Utilized Sites Remedial Action Program, ORO-831, March 1983.

dDOE guidelines specify that every reasonable effort shall be made to identify and to remove any source which has a concentration excecding 30) tumes the guideline value, irrespectuve of arca. (adkpted from Revised Guidelines for Residual Radioactive Material at FUSRAP and Remote SFMP Sites, April 1987).

Sources: Adapted from U.S. Departunent of Energy, Radiation Protection of the Public and the Environmant. DOE Order 5400.5, April 1990 and U.S. Deparment of Energy, Guidelines for Residual Radiancive Material at FUSRAP and Remole SFMP Siles, Rev. 2, March 1987.
} 
Table 2. Background radiation levels and concent rations of selected radionuclides in soil in the Beverly, Massachusetts, area

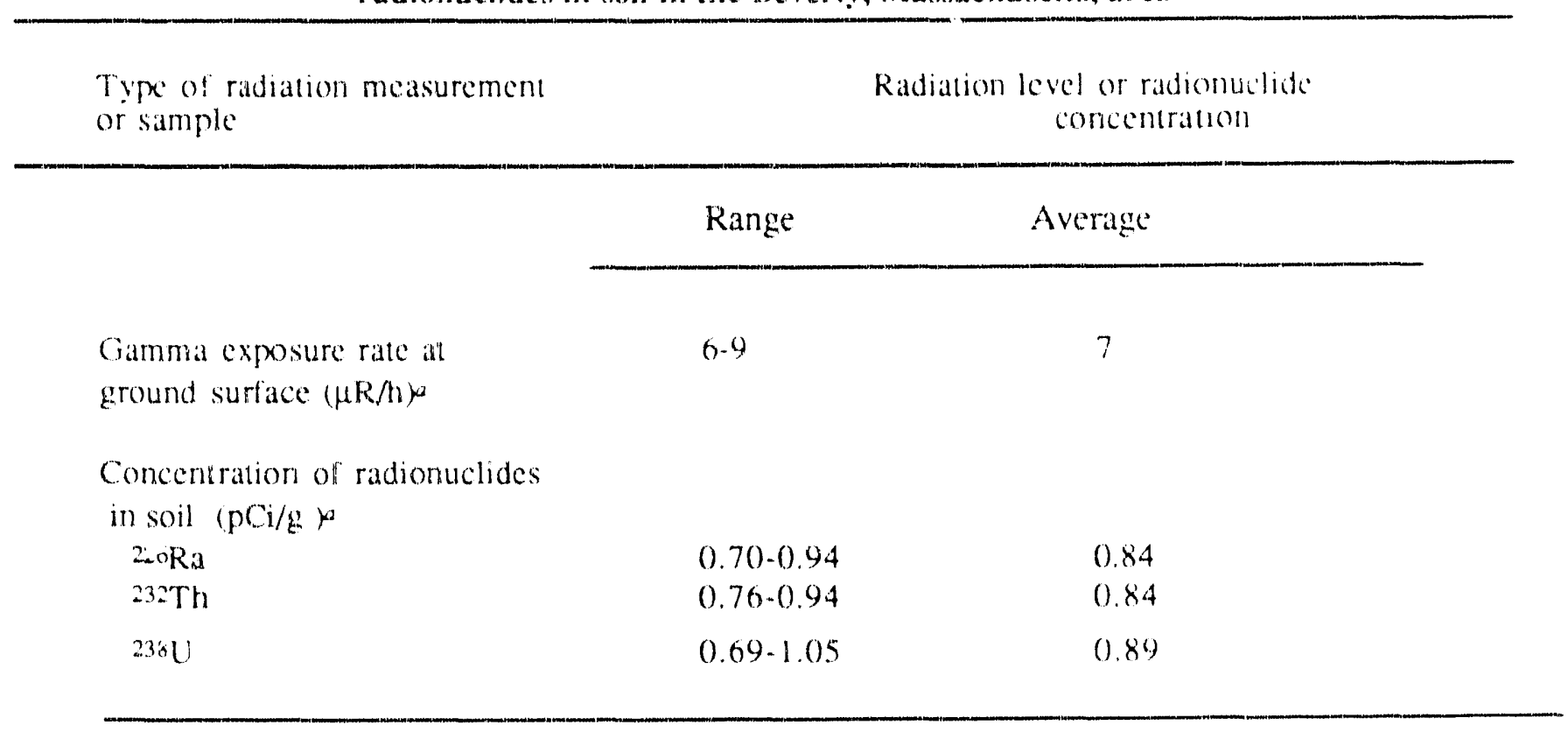

$a \vee$ alues obtained from three locations in the Beverly area. 
Table 3. Concentrations of radionuclides in soil samples from 19 Wellman Street, Beverly, Massachusetts

\begin{tabular}{|c|c|c|c|c|}
\hline \multirow{2}{*}{ Sample numberu } & \multirow{2}{*}{$\begin{array}{l}\text { Depth } \\
(\mathrm{cm})\end{array}$} & \multicolumn{3}{|c|}{ Radionuclide concentration $(p \mathrm{Ci} / \mathrm{g})^{t}$} \\
\hline & & $226 \mathrm{Ra}$ & $232 \mathrm{Th}$ & 2380 \\
\hline \multicolumn{5}{|c|}{ Systematic samples } \\
\hline S1A & 0.15 & $0.81 \pm 0.03$ & $0.96 \pm 0.04$ & $1.7 \pm 0.9$ \\
\hline$S I B$ & $15-30$ & $0.80 \pm 0.02$ & $1.0 \pm 0.0 .4$ & $1.2 \pm 0.5$ \\
\hline SIC & 3()$-36$ & $0.82 \pm 0.04$ & $1.1 \pm 0.08$ & $1.7 \pm 0.8$ \\
\hline$S 2 A$ & 0.15 & $0.89 \pm 0.02$ & $0.96 \pm 0.03$ & $1.7 \pm 0.5$ \\
\hline$S 2 B$ & $1.5 \cdot 30$ & $1.1 \pm 0.02$ & $1.2 \pm 0.04$ & $1.8 \pm 0.5$ \\
\hline$S 3 \mathrm{~A}$ & 0.15 & $1.5 \pm 0.02$ & $1.6 \pm 0.04$ & $3.2 \pm 0.6$ \\
\hline S3B & $15-30$ & $1.5 \pm 0.03$ & $1.6 \pm 0.04$ & $2.3 \pm 1$ \\
\hline S4A & $0-15$ & $1.8 \pm 0.04$ & $2.0 \pm 0.06$ & $3.4 \pm 1$ \\
\hline $\mathrm{S} 4 \mathrm{~B}$ & $15-30$ & $2.8 \pm 0.07$ & $3.0 \pm 0.1$ & $4.6 \pm 2$ \\
\hline$S 4 C$ & $30-45$ & $3.3 \pm 0.05$ & $3.7 \pm 0.08$ & $5.0 \pm 1$ \\
\hline$S 4 D$ & $45-61$ & $4.3 \pm 0.09$ & $4.5 \pm 0.1$ & $5.4 \pm 0.9$ \\
\hline S.5A & 0.15 & $0.89 \pm 0.02$ & $0.92 \pm 0.03$ & $1.6 \pm 0.9$ \\
\hline S6A & $15-30$ & $3.1 \pm 0.04$ & $3.3 \pm 0.06$ & $3.9 \pm 0.9$ \\
\hline S6B & $30-45$ & $3.4 \pm 0.07$ & $3.5 \pm 0.1$ & $4.9 \pm 2$ \\
\hline$S 6 C$ & $45-61$ & $3.4 \pm 0.04$ & $3.8 \pm 0.07$ & $3.7 \pm 1$ \\
\hline
\end{tabular}

aSample locations are shown on Fig. 3.

bIndicated counting error is at the $95 \%$ confidence level ( $\pm 2 \sigma$ ).

cSystematic samples are taken at locations irrespective of gamma exposure rates. 
ORNL/RASA-91/:0

\section{INTERNAL DISTRIBLTION}

\author{
1. B. A. Berven \\ 2. R. F. Carrier \\ 3. W. D. Courell \\ 4-9. R. D. Foley \\ 10. R. O. Hultgren \\ 11-14. C. A. Johnson \\ 15. S. V. Kave \\ 16. A. P. Malinauskas \\ 17. M. E. Murray \\ 18. P. T. Owen \\ 19. D. A. Roberts
}

\author{
20. R. E. Rodriguez \\ 21. P. S. Rohwer \\ 22-24. R. E. Swaja \\ 25. M. S. Uzicl \\ 20. J. K. Williams \\ 27. Central Research Library \\ 28-29. Laboratory Records \\ 30. Laboratory Records-RC \\ 31. ORNL Patent Section \\ 32. ORNL Technical Library, Y'-12 \\ 33-38. MAD Records Center
}

\section{EXTERNAL DISTRIBUTION}

39. J. D. Berger, Oak Ridge Associated Universities, E/SH Division, Envimnmental Survey and Site Assessment Program, P.O. Box 117, Oak Ridge, TN 37831-0117

40. James J. Fiore, Director, Office of Eastem Area Programs, Office of Environmental Restoration, U.S. Department of Energy, (EM-42), Trevion II, Washington, DC 20585

41-43. G. K. Hovey, Bechtel National, Inc., FUSRAP Department, Oak Ridge Corporate Center, 151 Lafayette Drive, P.O. Box 350, Oak Ridge, TN $37831-0350$

44. L. K. Price, Director, Former Sites Restoration Division, Oak Ridge Field Office, U.S. Deparment of Energy, P.O. Box 2001, Oak Ridge, 'TN 37831-8723

45. James W. Wagoner II, Director, Dvision of Off-Site Programs, Office of Eastem Area Programs, Office of Environmental Restoration, U.S. Deparment of Energy, (EM-421), Trevion II, Washington DC 20585

46-50. W. Alexander Williams, Designation and Certification Manager, Division of Off-Site Programs, Office of Eastem Area Programs, Office of Envimonmental Restoration, U.S. Deparment of Energy, (EM-421), Trevion II, Washington DC. 20585

51. C. D. Young, Office of Technical Services, Roy F. Weston, Inc., 12800 Middlebrook Road, Suite 207, Germantown, MD 20874

52-56. Office of Scientific and Technical Information, U.S. Deparument of Energy, P.O. Box 62, Oak Ridge, TN 37831 

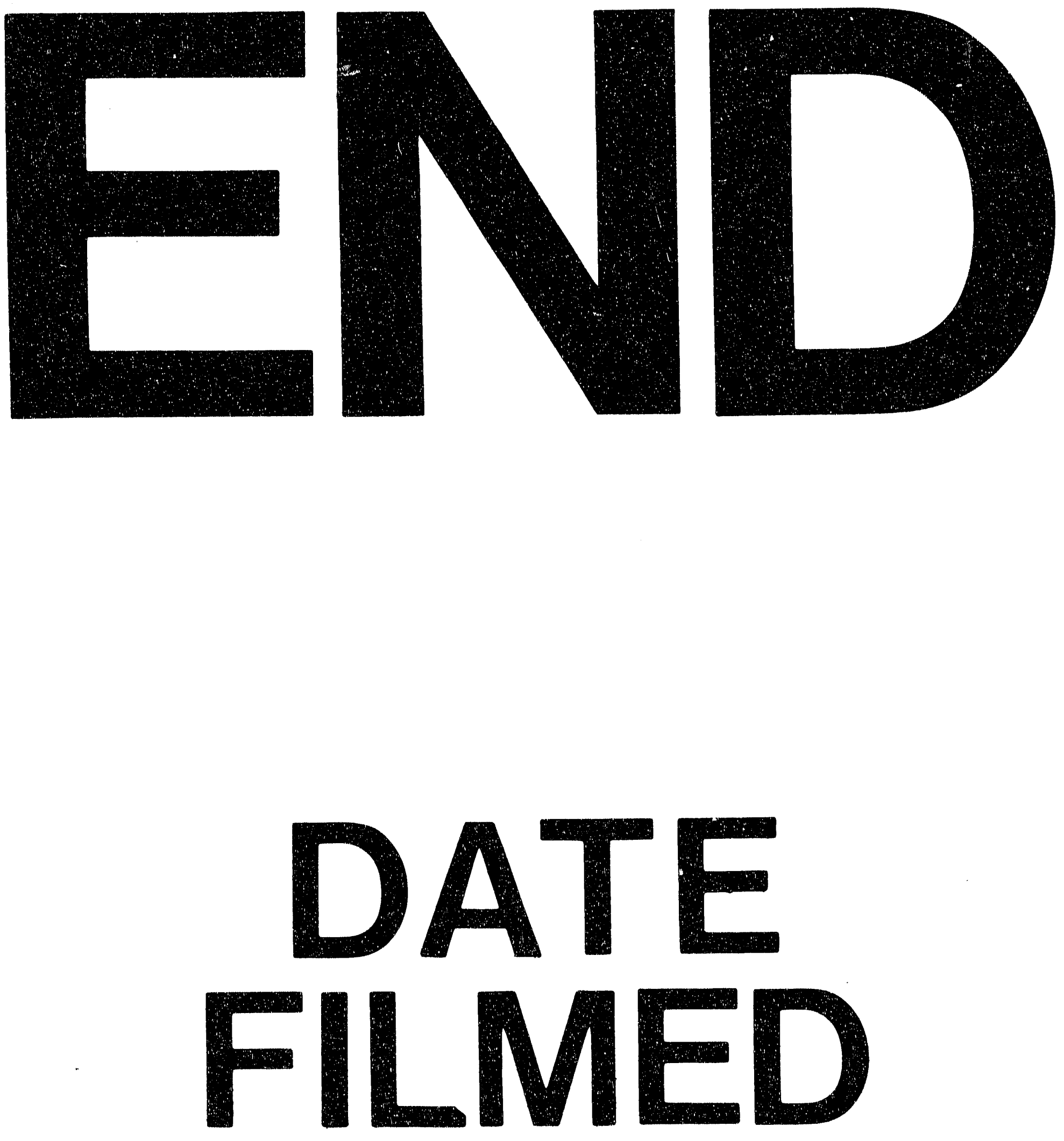

I

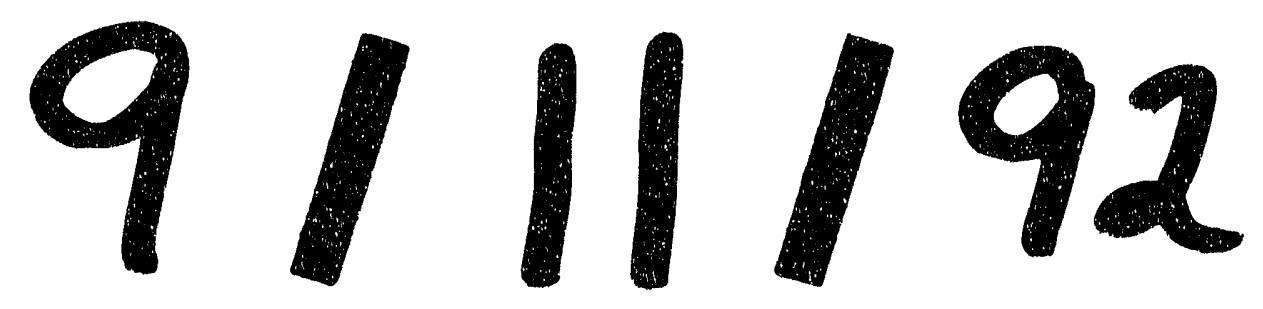


